\title{
NEST CHARACTERISTICS AND BREEDING SUCCESS OF BLACK KITES (MILVUS MIGRANS MIGRANS) IN THE HIGH PLATEAU (ALGERIA)
}

\author{
Sarra Messabhia ${ }^{a}$, Ettayib Bensaci ${ }^{b^{*}}$, Salah Telailiac, Abderraouf Chouaib Rebbah ${ }^{\mathrm{a}}$ and Menouar Saheb $^{\mathrm{a}}$ \\ ${ }^{a}$ Department of Nature and Life Sciences, Larbi Ben M'Hidi University of Oum El Bouaghi, PO Box 358, Oum El Bouaghi \\ 04000, Algeria; ${ }^{b}$ Department of Nature and Life Sciences, Mohamed Boudiaf University of M'sila, PO Box 166, M'sila 28000, \\ Algeria; ${ }^{c}$ Department of Agricultural Sciences, Chadli Bendjedid University of El-Tarf, PO Box 76, El-Tarf 36000, Algeria \\ Corresponding author. Email: bensacitayeb@yahoo.fr
}

\begin{abstract}
Article history
Received: 18 April 2018; accepted 7 January 2019
\end{abstract}

\section{Keywords:}

Black kite; Milvus migrans migrans; breeding success; nest characteristics; Algeria

\begin{abstract}
The breeding ecology of the Black Kite Milvus migrans migrans in Algeria was first studied in 2014 and 2015 on Tarf Mountain in the semi-arid High Plateaus region. The nearest-neighbour nest distance was found to range from 130 to $550 \mathrm{~m}$ for colonial pairs and from 1,730 to $2,390 \mathrm{~m}$ for the solitary ones. All 12 monitored nests were placed on cliffs at different heights ranging from 149 to $155 \mathrm{~m}$. The mean egg laying period was 15 days, and the mean clutch size was $2.83 \pm 0.31$ and 3 \pm 00 eggs per nest in 2014 and 2015, respectively. The mean hatching success was $83 \%$ and that of fledging $75 \%$. Only 2 nests were predated. Our results disagree with those of the previous studies that were carried out mainly in the Mediterranean basin and Asia, differing in such nest characteristics as the nearest-neighbour nest distance, cliff and nesting heights, egg laying period and hatching success. Otherwise, no consistent differences in clutch size and fledging success were revealed. Finally, we determined that Black Kites tend to build their nest on the eastern side of cliffs. However, our analysis showed no effect of nest placement on breeding parameters and success.
\end{abstract}

\section{INTRODUCTION}

The Black Kite is possibly the most common raptor in the world, except for the Nearctic and the Neotropic regions (Ferguson-Lees and Christie 2001). It is a widespread species in Palearctic, Afro-Malagasy, Indomalayan and Australian regions (Panuccio et al. 2013; Nunes et al. 2015). The global population size is in the range of 1,470,000-1,980,000 mature individuals, the European population representing $11 \%$ of this number, with 81,200-109,000 breeding pairs (BirdLife International 2016). From six known sub-species (Cramp and Simmons 1983), Milvus migrans migrans is the only one to live and breed in the region of North Africa (Heim DeBalsac and Mayaud 1962).

In Morocco, it is an abundant migrant and a common species breeding from the Mediterranean coast to the southern High Atlas (Thévenot, Vernon, and Bergier 2003). In Algeria, it is distributed from the coast to the northern edge of the Sahara (Isenmann and Moali 2000). It is also very common both in the Tell (Ledant et al. 1981) and Ksours Mounts (Blondel 1962a).

In Europe and Asia, the Black Kite's breeding ecology and its breeding success have been widely studied (Desai and Malhotra 1979; Koga, Siraishi, and Uchida 1989; Viñuela and Veiga 1992; Sergio and Boto 1999). However, no study on the Black Kite's breeding ecology and its breeding success has been carried out in North Africa.
In Algeria, raptors have received very little attention from ornithologists. The main studies that were carried out were based on observations intermittently conducted in limited geographical areas (Balsac and Mayaud 1962; François 1975; Blondel 1962a, b, c; Ledant et al. 1981; Roché 1982). Recent papers have provided an update on the status and distribution of some raptor species on the Algerian coastline (Moali and Gaci 1992; Telailia et al. 2013; Touati et al. 2017).

The present study aimed to monitor the Black Kite during its breeding season and provide information on some aspects of its breeding ecology and nest site selection in Algeria.

\section{MATERIALS AND METHODS}

\section{Study area}

The High Plateau is located between the Saharan Atlas mountain range and narrow coastal plains of Algeria. This transitional area contains a large diversity of habitats such as mountains, valleys and plateaus, with the landscape dominated by steppe vegetation.

The Black Kite breeds on Tarf Mountain $\left(35^{\circ} 50^{\prime} \mathrm{N}\right.$, $07^{\circ} 10^{\prime} \mathrm{E}$ ) located in the eastern High Plateau of Algeria (Figure 1). The monitored breeding site was located approximately at a distance of $1 \mathrm{~km}$ from the road, and $4 \mathrm{~km}$ from the wild dump of the nearest slaughterhouse. 
The elevation of the mountain is $1,134 \mathrm{~m}$ a.s.l. and the area covered is around $37.57 \mathrm{~km}^{2}$ (Rekkab, Ziari, and Lamri 2008). The climate is semi-arid, with the annual mean temperature of $15.5^{\circ} \mathrm{C}$ and the average annual rainfall of less than $400 \mathrm{~mm}$. This fissured calcareous rock mountain (Karst) is rich in boulders, cliffs and degraded formations of gorse. Cliffs and shrubs (mainly Pistacia lentiscus) growing on cliff faces provide shelter and refuge for Black Kites. The landscape is dominated by xerophilous aridity-adapted vegetation. Trees are scattered among steppe plants that are mainly represented by Diss Ampelodesmos mauritanicus and White wormwood Atemisia herba-alba.

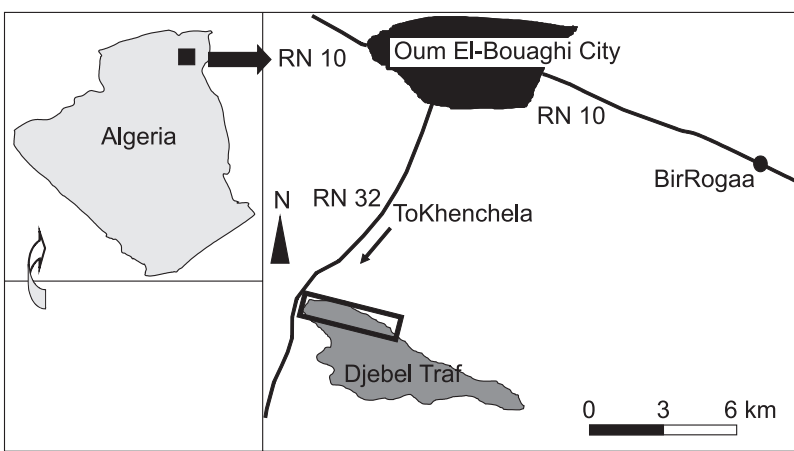

Figure 1. Location of the study area.

\section{Data collection}

The total duration of the surveys conducted over 2014 and 2015 for the purpose of locating breeding and nesting sites of the Black Kite was 180 days. Search for raptors and observation of their flight and display in March were conducted employing the on-foot survey method (Fuller and Mosher 1987), which allows accessing roadless tracts (Burnham and Mattox 1984), and rugged fields (Forsman 1983). Nest locations were recorded using a Garmin GPS. The geographic position of each nest was calculated from the nearest accessible point. A laser telemeter was used to calculate both cliff and nest heights. The orientation of nests was measured using a Garmin GPS with a Compass. After the geographic position of a nest had been determined, we estimated inter-nest distances using Google earth software.

The observation of egg and chick numbers in inaccessible nests was carried out with a perched Endoscopic Camera or binoculars and a high zoom camera (Canon $\times 46$ ).

The pairs nesting at a distance of $700 \mathrm{~m}$ from the nearest nest were defined as solitary, while those nesting within a $700 \mathrm{~m}$ distance from the nearest nest (Sergio and Boto 1999) as colonial. To minimize the risk of disturbance and desertion, during incubation or hatching periods nests were inspected briefly. The age of nestlings was estimated approximately according to their feathering and behavioral characteristics with an error of \pm 3 days (Minganti 2012).
Egg laying and hatching dates were estimated by backdating, assuming that the mean incubation period is 29 days and the mean raising period is 47 days long (Cramp and Simmons 1983).

We defined hatching success as the proportion of hatched eggs to hatched + unhatched ones, and fledging success as the proportion of fledged chicks to hatched eggs.

\section{Data analyses}

Statistical tests were performed using SPSS 18.0 with a significance level of $p \leq 0.05$. The main aim was to investigate the possible effects of nest placement on the following breeding parameters: clutch size, hatching and fledging successes. All variables were tested for normality using probability plots and the KolmogorovSmirnov test. Data were analyzed using both parametric and non-parametric tests (Chi-squared test, sample $t$-test, Mann-Whitney test and one-way ANOVA Spearman Rank correlation). All means are presented \pm standard error unless stated otherwise.

\section{RESULTS}

\section{Nest placement characteristics and site utilization}

Eight nests were studied in 2014 and four in 2015. The mean of the nearest nest distance (NND) increased from $352 \pm 197.77 \mathrm{~m}$ in 2014 to $812.5 \pm 529.4 \mathrm{~m}$ in 2015 . The average NND did not differ significantly between years $(t=$ $1.01, \mathrm{df}=10, p=0.337)$. NNDs varied between $130 \mathrm{~m}$ and $550 \mathrm{~m}$ for colonial pairs and between $1,730 \mathrm{~m}$ and $2,390 \mathrm{~m}$ for solitary pairs. The nest altitude ranged from $998 \mathrm{~m}$ to $1004 \mathrm{~m}$. No significant difference was found in nest altitude between 2014 and $2015(t=1.91, \mathrm{df}=10, p=0.856)$. All the nests were located in 3 different places on cliffs: $50 \%$ of the nests were placed on bare rock ledges, $33 \%$ in holes and $17 \%$ on cliff faces covered by shrub vegetation. Cliff heights ranging from $149 \mathrm{~m}$ to $155 \mathrm{~m}$ did not differ significantly between the years of survey $(t=0.202, \mathrm{df}=$ $10, p=0.844)$ and neither did nest heights $(t=0.202$, df $=10, p=0.847)$, which were in the range $18.59-20.25 \mathrm{~m}$ (Table 1). Therefore, significant correlations were revealed between NND and cliff height ( $\mathrm{rs}=0.835, \mathrm{~N}=12, p<$ $0.05)$, nest height ( $\mathrm{rs}=0.761, \mathrm{~N}=12, p<0.05)$ and cliff height $(\mathrm{rs}=0.835, \mathrm{~N}=12, p<0.05)($ Table 2$)$.

\section{Laying period}

The egg laying period lasted for 14 and 16 days in 2014 and 2015, respectively, with the first recorded egg laid on 7 April in 2014 and on 5 April in 2015 (Figure 2).

\section{Clutch size}

Clutch size ranged from 1 to 4 eggs (Figure 3 ). The mean clutch size was $2.83 \pm 0.31$ eggs per nest, with no 
difference noted between the years $(t=0.542, \mathrm{df}=10$, $p=0.599)$ and no clutch replacement observed in the same nest after breeding failures.

\section{Hatching and fledging success}

The hatching period started on 11 May in 2014 and on 7 May in 2015 and lasted for 14 and 16 days, respectively. The peak of egg hatching was observed between 13 and 18 May in 2014 (Figure 4). The nests, which were monitored from laying until hatching and fledging, had a high hatching (73\%) and fledging success (75\%). Two nests proved to have been predated, the Northern Raven Corvus corax being the main egg and chick predator. There was no significant difference recorded in hatching success between the survey years (Mann-Whitney $U$-test, $U=4, p=0.215$ ), the percentage of hatching success ranging between $62 \%$ and $85 \%$. The percentage of fledging success varied from $60 \%$ to $91 \%$ both in 2015 and 2014, respectively, with no significant difference between these years recorded (Mann-Whitney $U$-test, $U=16, p=0.99$ ).

\section{Nest-site selection and breeding success}

No significant correlations were revealed between nest placement parameters (nest height, cliff height and altitude) and those of breeding success (hatching success and fledging success) (Table 3). However, there was a significant

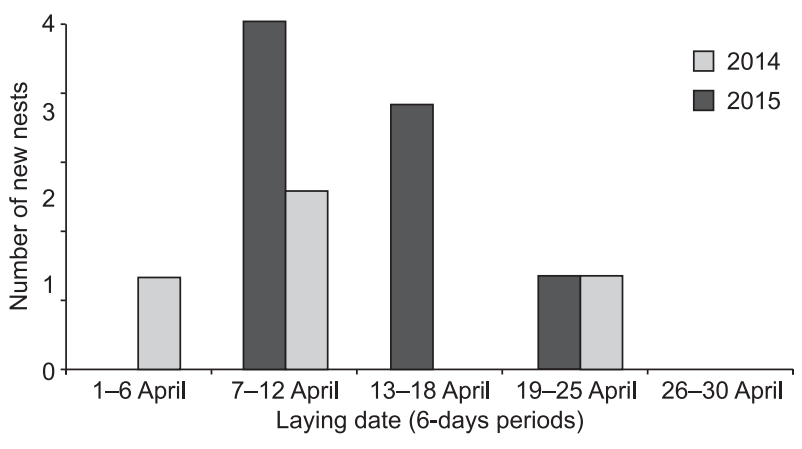

Figure 2. Evolution of egg-laying in 6-day periods at/on Tarf Mountain, Algeria in 2014 and 2015.

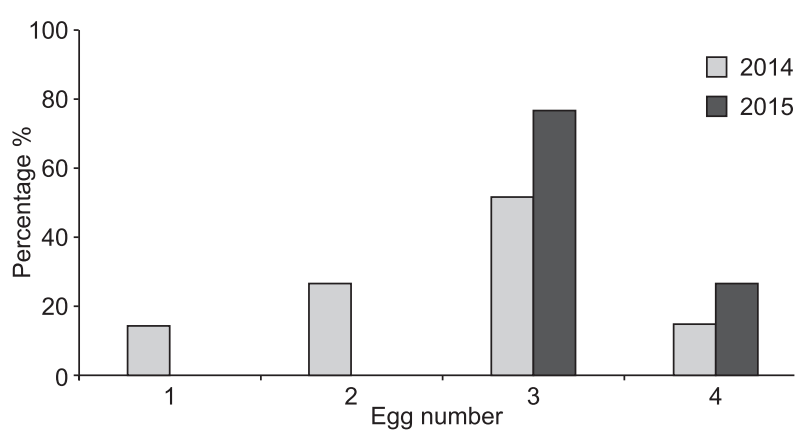

Figure 3. Frequency distribution of clutch size in 2014 and 2015.

Table 1. Nest placement and breeding parameters (mean $\pm 1 \mathrm{SE}$ ) of the Black Kite breeding on Tarf Mountain, Algeria 2014 and 2015.

\begin{tabular}{|l|c|c|c|c|}
\hline \multirow{2}{*}{ Parameters $(\mathrm{m})$} & \multicolumn{2}{|c|}{ Year } & \multirow{2}{*}{$t$} \\
\cline { 2 - 3 } & 2014 & 2015 & 0.542 & 0.599 \\
\hline Clutch size & $2.63 \pm 0.32$ & $3.25 \pm 0.25$ & 12 & 0.94 \\
\hline Hatching rate & $46.63 \pm 10.61$ & $85.25 \pm 8.71$ & 1.01 & 0.337 \\
\hline NND & $352.50 \pm 197.77$ & $812.50 \pm 529.4$ & 0.202 & 0.844 \\
\hline Cliff height & $149.13 \pm 16.63$ & $155.25 \pm 27.45$ & 1.91 & 0.856 \\
\hline Altitude & $998.13 \pm 16$ & $1004.25 \pm 27.45$ & 0.202 & 0.847 \\
\hline Nest height & $18.58 \pm 4.44$ & $20.25 \pm 6.95$ & \\
\hline
\end{tabular}

$\mathrm{NND}=$ Nearest-neighbour nest distance (the nearest nest).

Table 2. Correlations between measured nest placement parameters.

\begin{tabular}{|c|c|c|c|c|c|}
\hline & & Cliff height (m) & Altitude (m) & Nest height (m) & $\mathrm{NND}(\mathrm{m})$ \\
\hline \multirow[t]{3}{*}{ Cliff height } & Pearson Correlation & 1 & $1.000^{* *}$ & .532 & $.835^{* *}$ \\
\hline & Sig. (2-tailed) & & .000 & .075 & .001 \\
\hline & $\mathrm{N}$ & 12 & 12 & 12 & 12 \\
\hline \multirow[t]{3}{*}{ Altitude } & Pearson Correlation & $1.000^{* *}$ & 1 & .532 & $.835^{* *}$ \\
\hline & Sig. (2-tailed) & .000 & & .075 & .001 \\
\hline & $\mathrm{N}$ & 12 & 12 & 12 & 12 \\
\hline \multirow[t]{3}{*}{ Nest height (m) } & Pearson Correlation & .532 & .532 & 1 & $.761^{* *}$ \\
\hline & Sig. (2-tailed) & .075 & .075 & & .004 \\
\hline & $\mathrm{N}$ & 12 & 12 & 12 & 12 \\
\hline \multirow[t]{3}{*}{ NND } & Pearson Correlation & $.835^{* *}$ & $.835^{* *}$ & $.761^{* *}$ & 1 \\
\hline & Sig. (2-tailed) & .001 & .001 & .004 & \\
\hline & $\mathrm{N}$ & 12 & 12 & 12 & 12 \\
\hline
\end{tabular}

\footnotetext{
** Correlation is significant at the 0.01 level (2-tailed).
} 
negative correlation found to exist between the inter-nest distance and the rate of hatching success ( $\mathrm{rs}=-0.66, \mathrm{~N}=$ $12, p=0.022$ ), and that of fledging success ( $\mathrm{rs}=-0.67$, $\mathrm{N}=12, p=0.011$ ). Also, our study showed that clutch size was strongly dependent on nest exposure $(\mathrm{X}(12)=$ $21.07, p=0.049$ ) (Table 4). However, nest exposure (X (4) $=1.8, p=0.772)$ was not found to affect either hatching or fledging success $(\mathrm{X}(4)=4.44, p=0.349)$.

\section{DISCUSSION}

One of the main aims of this study was to provide preliminary information on ecological aspects of the Black Kite breeding in Algeria and, particularly, in the High Plateau region. Although the study area is

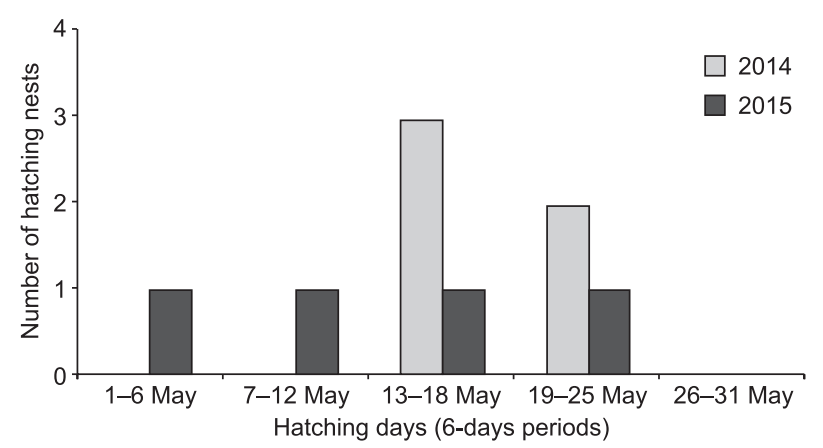

Figure 4. Evolution of hatching in 6-day periods at/on Tarf Mountain, Algeria in 2014 and 2015. dominated by the steppe, it is considered to be a representative sample of the High Plateau. However, Tarf Mountain, is the main habitat suitable for eagles and raptors of this region and is used for breeding by most species. This species is the most adaptable, numerous, opportunistic and the most successful raptor in the world, greatly benefiting from its closer association with man and human environment (Zocchi and Lacroix 2004; Tanferna et al. 2013; Naoroji and Sangha 2013). It often nests in loose colonies, but sometimes solitarily in couples (Thévenot, Vernon, and Bergier 2003; Sergio et al. 2005; Panuccio et al. 2013), which was also the case in our study.

Throughout our survey we found 2 loose colonies and 2 solitary couples. The mean of the nearest-neighbor nest distance of the Black Kite breeding on Tarf Mountain $(\mathrm{MNND}=582.5 \pm 363.6 \mathrm{~m})$ was approximately the same as the one found in the Tolfa mountains, Italy (MNND $=611 \pm 94 \mathrm{~m}$ ) (Minganti 2012), but much shorter than the one recorded by Seelig et al. (1996) in Dromling, Germany $(\mathrm{MNND}=2330 \mathrm{~m})$, by Koga and Shiraishi (1994a) in Nagasaki Peninsula, Japan ( MNND = 80 m), and much longer than the one recorded in Costel Porziano, Italy (MNND = 103 m) (De Giacomo, Martucci, and Tinelli 1993), in Delhi, India $($ MNND = $133 \mathrm{~m}$ ) (Kumar et al. 2014) and in Donana, Spain (MNND = 206 m) (Hiraldo, Veiga, and Manez 1990). These variations in NNDs may be related to food abundance (Koga, Siraishi, and Uchida 1989; Sergio and Boto 1999;

Table 3. Correlations between measured nest placement parameters and breeding success.

\begin{tabular}{|c|c|c|c|c|c|c|}
\hline & & $\begin{array}{l}\text { Nest height } \\
(\mathrm{m})\end{array}$ & $\begin{array}{l}\text { Cliff height } \\
(\mathrm{m})\end{array}$ & $\begin{array}{l}\text { Altitude } \\
(\mathrm{m})\end{array}$ & $\begin{array}{c}\text { Hatching } \\
\text { success }(\%)\end{array}$ & $\begin{array}{c}\text { Fledging } \\
\text { success }(\%)\end{array}$ \\
\hline \multirow[t]{3}{*}{ Nest height } & Pearson Correlation & 1 & .532 & $1.000^{* *}$ & .293 & .389 \\
\hline & Sig. (2-tailed) & & .075 & .000 & .356 & .212 \\
\hline & $\mathrm{N}$ & 12 & 12 & 12 & 12 & 12 \\
\hline \multirow[t]{3}{*}{ Cliff height (m) } & Pearson Correlation & .532 & 1 & .532 & -.249 & -.098 \\
\hline & Sig. (2-tailed) & .075 & & .075 & .436 & .761 \\
\hline & $\mathrm{N}$ & 12 & 12 & 12 & 12 & 12 \\
\hline \multirow[t]{3}{*}{ Altitude } & Pearson Correlation & $1.000^{* *}$ & .532 & 1 & .293 & .389 \\
\hline & Sig. (2-tailed) & .000 & .075 & & .356 & .212 \\
\hline & $\mathrm{N}$ & 12 & 12 & 12 & 12 & 12 \\
\hline \multirow[t]{3}{*}{ Hatching success $\%$} & Pearson Correlation & .293 & -.249 & .293 & 1 & $.775^{* *}$ \\
\hline & Sig. (2-tailed) & .356 & .436 & .356 & & .003 \\
\hline & $\mathrm{N}$ & 12 & 12 & 12 & 12 & 12 \\
\hline \multirow[t]{3}{*}{ Fledging success \% } & Pearson Correlation & .389 & -.098 & .389 & $.775^{* *}$ & 1 \\
\hline & Sig. (2-tailed) & .212 & .761 & .212 & .003 & \\
\hline & $\mathrm{N}$ & 12 & 12 & 12 & 12 & 12 \\
\hline
\end{tabular}

** Correlation is significant at the 0.01 level (2-tailed).

Table 4. Main data on breeding success.

\begin{tabular}{|l|c|c|c|c|c|c|}
\hline \multirow{2}{*}{} & \multicolumn{3}{|c|}{2014} & \multicolumn{3}{c|}{2015} \\
\cline { 2 - 8 } & Mean \pm SE & Max & Min & Mean \pm SE & Max & Min \\
\hline Number of nestlings fledged per breeding & $1.25 \pm 0.37$ & 3 & 0 & $2 \pm 0.71$ & 3 & 0 \\
\hline Number of nestlings fledged per successful pair & $1.67 \pm 0.33$ & 3 & 1 & $2.67 \pm 0.33$ & 3 & 2 \\
\hline
\end{tabular}


Kumar et al. 2014) and the competition with other raptor species nesting on the same cliffs. Therefore, the aggregation of the Black Kite on the western side of Tarf Mountain is probably due to the closest distance to the road $(1.5 \mathrm{~km})$, which provides food for this raptor through road accidents and the closest distance to the waste dump of the slaughterhouse $(4.7 \mathrm{~km})$ as the Black Kite tends to build its nests near foraging sites (Sharma and Soni 2016) and in the vicinity of the cliffs suitable for nesting. The Black Kite typically nests in trees (Thiollay 1967; Koga, Siraishi, and Uchida 1989; Zawadzka 1999; Kirwan et al. 2008; Zocchi and Lacroix 2004; Kumar et al. 2014) and also on cliffs, a very common habitat all over the Mediterranean basin (Brosset 1959; Heim DeBalsac and Mayaud 1962; Schifferli, Géroudet, and Winkler 1980; Blanco 1997; Sergio and Boto 1999). However, in the case of our study, nests were built in cavities, on cliff edges or often in shrubs (Pistacia lentiscus) growing on cliff faces. In our study, the mean nest height $(19.41 \pm 5.69 \mathrm{~m})$ was found to be lower than that reported by Sergio, Pedrini, and Marchesi (2003) (29.3 $\pm 3.7 \mathrm{~m}$ ) at Lake Lugano (Italian pre-Alps). The choice of cliffs for nesting is probably the tactic used by Black Kites to avoid human disturbance, persecution and terrestrial predators, because nests on cliffs are higher and less accessible than those in trees (Maurizio 2003; Sergio, Pedrini, and Marchesi 2003). In early March, Black Kites started to arrive and display courtship behavior. Egg laying began in the first week of April, which is later than in Japan (first half of March) as reported by Koga and Shiraishi (1994). The egg laying period on Tarf Mountain lasted from 14 to 16 days, but in the Italian Pre-Alps, it lasted for more than 25 days, i.e. it was 9 days longer (Sergio and Boto 1999). Our results showed a shorter laying period than those found in Japan by Koga and Shiraishi (1994b), and in Italy by Sergio, Pedrini, and Marchesi (2003), which is probably due to the Black Kite's strategy for saving energy and shortening egg laying period by reusing its old nests and also those of other species, e.g. the nests of Buteo rufinus cirtensis, Falco peregrinus, Hieraaetus pennatus, Neophron percnopterus. The mean clutch size of this raptor on Tarf Mountain was similar to those recorded in Slovakia (Danko 1989, 2.98), France (Thiollay 1967, 2.26), and in Japan (Koga, Siraishi, and Uchida 1989, 2.18).

The present study highlights the hatching success of $83 \%$, which is greater than that found in New Delhi (55\%) (Desai and Malhotra 1979), but similar to the results (84\%) obtained in Italy (Sergio and Boto 1999). According to Bustamante and Hiraldo (1989), juveniles started their first flights from 42 to 62 days after hatching. In our study, the fledging success was $75 \%$, i.e. almost the same as the one recorded in Japan (Koga, Siraishi, and Uchida 1989), which is due to the availability of food that allowed the parents to be close to the nest and insure adequate protection of their chicks (Sharma and Soni 2016). This study also analyzed the effect of nest location on some breeding parameters. Our results show that there is a clear tendency for Black Kites to build their nests on the northeastern or southeastern sides of cliffs (NE: $33.33 \%$, SW: $25 \%$ ), which is in agreement with the study results obtained in Spain (Viñuela and Sunyer 1992). Nest orientation can affect its exposure to some climate parameters (Long, Jensen, and With 2009). Although Viñuela and Sunyer (1992) reported that hatching success is affected by nest orientation, results of our study did not confirm that, i.e. nest exposure was not found to affect the rates of either hatching or fledging success. In general, the latitudinal variation in nest orientation is consistent with the conjecture that birds orient their nests either towards the sun or seek shelter from solar radiation (Burton 2007).

Preliminary findings of the study on the breeding aspects of the Black Kite in Algeria are expected to provide the baseline data for further detailed monitoring and investigations aimed to improve the knowledge of environmental preferences and factors affecting nesting site selection by this raptor. Further long-term investigations covering a large range of habitats are needed to identify more factors influencing the Black Kite's breeding success.

\section{ACKNOWLEDGEMENTS}

We are grateful to Dr Patrick Triplet (Director of Baie de Somme Nature Reserve) for his scientific lecture, and Mr Youcef-khoudja Nazih for preparing the map. We thank members of the Association Nationale Algérienne d'Ornithologie (A.N.A.O), and the PhD students of University of Oum El Bouaghi, for their invaluable field assistance. We express our sincere thanks to two anonymous referees whose suggestions and comments greatly improved our manuscript.

\section{Disclosure statement}

No potential conflict of interest was reported by the authors.

\section{ORCID}

Sarra Messabhia http://orcid.org/0000-0003-04509181

\section{REFERENCES}

BirdLife International. 2016. Milvus migrans. The IUCN Red List of Threatened Species 2016.

Blanco, G. 1997. 'Role of Refuse as Food for Migrant, 
Floater and Breeding Black Kites (Milvus migrans).' Journal of Raptor Research 31: 71-76.

Blondel, J. 1962a. 'DonnéeEcologique surl'Avifaune des Monts des Ksours (Sahara Septentrional).' [Ecological Data on the Avifauna of the Ksours's Mountains (Northern Sahara)]. Terre Et Vie 3: 209-251.

Blondel, J. 1962b. 'Migration Prénuptia ledans les Monts des Ksours (Sahara septentrional).' [Pre-Nuptial Migration in the Ksours's Mountains (Northern Sahara)]. Alauda 30: 1-29.

Blondel, J. 1962c. 'Observation d'un Aigle Impérial dans les Monts des Ksours.' [Observation of an Eastern Imperial Eagle in the Ksours's Mountains]. Alauda 30: 69.

Brosset, A. 1959. Ecologie des oiseaux du Maroc oriental. [Birds Ecology of Eastern Morocco]. PhD Thesis, University of Lille1.

Burnham, W. A., and W. G. Mattox. 1984. 'Biology of the Peregrine and Gyrfalcon in Greenland.'Bioscience 14: $1-28$.

Burton, N. H. K. 2007. 'Intraspecific Latitudinal Variation in Nest Orientation Among Ground-Nesting Passerines: A Study Using Published Data.' Condor 109: 441-446.

Bustamante, J., and F. Hiraldo.1989. 'Post-Fledging Dependence Period and Maturation of Flight Skill in the Black Kite Milvus migrans.' Bird Study 36: 199-204.

Cramp, S., and K. E. L. Simmons. 1983. Handbook of the Birds of Europe, the Middle East and North Africa: The Birds of the Western Palearctic. Vol. 3. Oxford: University Press.

Danko, S. 1989. 'Five Young in the Nest of a Black Kite (Milvus migrans).' Buteo 4: 87-92.

De Giacomo, U., O. Martucci, and A. Tinelli. 1993. 'L'alimentazione Del Nibbiobruno (Milvus migrans) nellaTenuta di Castel porziano (Roma).' [The Diet of the Black Kite (Milvus migrans) in Castel porziano Estate (Rome)]. Avocetta 17: 73-78.

Desai, J. H., and A. K. Malhotra. 1979. 'Breeding Biology of the Pariah Kite Milvus migrans at Delhi Zoological Park.' Ibis 121: 320-325.

Ferguson-Lees, J., and D. A. Christie. 2001. Raptors of the World. New York: Houghton Miffin Company.

Forsman, E. D. 1983. Methods and Materials for Locating and Studying Spotted Owls. General Technical Report $P N W-162$. United States: Department of Agriculture, Forest Service.

François, J. 1975. 'Contribution à la connaissance de l'avifauned'Afrique du Nord.' [Contribution to the knowledge of the North African Avifauna]. Alauda 43: 279-293.

Fuller, M. R., and J. A. Mosher. 1987. Raptor survey techniques. Washington: National Wildlife Federation.

Heim DeBalsac, H., and N. Mayaud. 1962. Les Oiseaux du Nord de l'Afrique [Birds of North Africa]. Paris: Lechevalier.

Hiraldo, F., J. P. Veiga, and M. Manez. 1990. 'Growth of
Nestling Black kites Milvus migrans: Effects of Hatching Order, Weather and Season.' Journal of Zoology 222: 197-214.

Isenmann, P., and A. Moali. 2000. Oiseaux D'Algérie [Birds of Algeria]. Paris: Sociétéd'Etudes Ornithologiques de France.

Kirwan, G. M., K. Boyla, P. Castell, B. Demirci, M. Özen, H. Welch, and T. Marlow. 2008. The birds of Turkey. London: Christopher Helm.

Koga, K., S. Siraishi, and T. A. Uchida. 1989. 'Breeding Ecology of the Black-eared Kite Milvus migrans lineatus in the Nagasaki Peninsula, Kyushu.' Japanese Journal of Ornithology 38: 57-66.

Koga, K., and S. Shiraishi. 1994a. 'Copulation Behavior of the Black Kite Milvus migrans in Nagasaki Peninsula.' Bird Study 41: 29-36.

Koga, K., and S. Shiraishi. 1994b. 'Parent-Offspring Relations during the Post-Fledging Dependency Period in the Black Kite (Milvus migrans) in Japan.' Journal of Raptor Research 28 (3): 171-177.

Kumar, N., D. Mohan, Y. V. Jhala, Q. Qureshi, and F. Sergio. 2014. 'Density, Laying Date, Breeding Success and Diet of Black Kites Milvus migrans govinda in the City of Delhi (India).' Bird Study 61: 1-8.

Ledant, J. P., J. P. Jacob, P. Jacobs, F. Malher, B. Ochando, and J. Roche. 1981. 'Miseà jour de l'avifaunealgérienne.' [Update of the Algerian Avifauna]. Gerfaut 71: 295-394.

Long, A. M., W. E. Jensen, and K. A. With. 2009. 'Orientation of Grasshopper Sparrow and Eastern Meadowlark nests in relation to wind direction.' The Condor 111 (2): 395-399.

Maurizio, S. 2003. 'The Colonization of Sicily by the Black Kite (Milvus migrans).' Journal of Raptor Research 37 (2): 167-172.

Minganti, A. 2012. Ecological Overlap between Two Sympatric Birds of Prey (Milvus milvus and Milvus migrans) During the Breeding Season. PhD thesis, University of Degli Study.

Moali, A., and B. Gaci. 1992. 'Les Rapaces diurnes nicheurs en Kabylie.' [Diurnal Birds of Prey Nesting in Kabylie]. Alauda 60: 164-169.

Naoroji, R., and S. Sangha. 2013. 'Status and Distribution of Raptors in Rajasthan.' In Faunal Heritage of Rajasthan, India, edited by Sharma B. K., S. Kulshreshtha, and A. R. Rahmani, 357-409. New York: Springer.

Nunes, G. T., L. S. Hoffmann, B. C. L. Macena, G. A. Bencke, and L. Bugoni. 2015. 'A Black Kite Milvus migrans on the Saint Peter and Saint Paul Archipelago, Brazil.' Revista Brasileira de Ornitologia 23 (1): 31-35.

Panuccio, M., N. Agostini, U. Mellone, and G. Bogliani. 2013. 'Circannual Variation in Movement Patterns of the Black Kite (Milvus migrans migrans): a Review.' Ethology Ecology and Evolution 26 (1): 1-18.

Rekkab, S., L. Ziari, and M. Lamri. 2008. Inventairesur le 
centre-villed'Oum El-Bouaghi vers la creation d'un centre unique. [Inventory on the Downtown of Oum El-BouaghiTowards the Creation of a Single Center] State Engineer Thesis. University of Larbi ben M'hidi OEB.

Roché, J. 1982. 'Nidification probable de l'Aigle pomarin Aquila pomarina en Algérie.' [Probability of Nesting of the Lesser Spotted Eagle Aquila pomarina in Algeria]. L'Oiseauet la Revue Françaised'Ornithologie 52: 367-369.

Schifferli, L., P. Géroudet, and R. Winkler. 1980. Atlas des oiseauxnicheurs de Suisse [Atlas of the Breeding Birds of Switzerland]. Switzerland: Station Ornithologique de Sempach.

Seelig, K., H. Benecke, F. Braumann, and B. Nicolai. 1996. Die Vogel im Naturpark Dromling [The Birds in the Dromling Nature Park]. Halberstadt: Förderkreis Museum Heineanum.

Sergio, F., and A. Boto. 1999. 'Nest Dispersion, Diet, and Breeding Success of Black Kites (Milvus migrans) in the Italian Pre-Alps.' Journal of Raptor Research 33 (3): 207-217.

Sergio, F., P. Pedrini, and L. Marchesi. 2003. 'Adaptive Selection of Foraging and Nesting Habitat by Black Kites (Milvus migrans) and its Implications for Conservation: a Multi-Scale Approach.' Biological Conservation 112: 351-362.

Sergio, F., J. Blas, M. Forero, N. Fernandez, J. A. Donazar, and F. Hiraldo. 2005. 'Preservation of Wide-Ranging top Predators by Site-Protection: Black and Red kites in Donana National Park.' Biological Conservation 125 (1): 11-21.

Sharma, S. K., and K. C. Soni. 2016. 'Nesting Ecology, Interspecific Interaction and Nesting Association of Indian Black Kite (Milvus migrans) Inhabiting the Arid Zone of Rajasthan.' Interlink Continental Journal of Medicine \& Medical Sciences 2 (4): 17-26.
Tanferna, A., L. López-Jiménez, J. Blas, F. Hiraldo, and F. Sergio. 2013. 'Habitat Selection by Black kite Breeders and Floaters: Implications for Conservation Management of Raptor Floaters.' Biological Conservation 160: 1-9.

Telailia, S., M. Saheb, L. Boutabia, M. A. Bensouilah, and M. Houhamdi. 2013. 'Breeding biology of Eleonora's Falcon, Falco eleonorae Gené, 1839 (Accipitriformes Falconidae), in Northeast Algeria at Sérigina Island.' Biodiversity Journal 4 (1): 117-124.

Thévenot, M., J. D. R. Vernon, and P. Bergier. 2003. The Birds of Morocco. British Ornithologists Union Checklist Series 20. Tring: British Ornithologists' Union.

Thiollay, J. M. 1967. 'Ecologied'une population de rapaces diurnes en Lorraine.' [Ecology of the Diurnal Raptors Population in Lorraine]. La Terre et la Vie 114: 116-183.

Touati, L., R. Nedjah, F. Samraoui, A. H. Alfarhan, L. Gangoso, J. Figuerola, and B. Samraoui. 2017. 'Select On the Brink: Status and Breeding Ecology of Eleonora's Falcon Falco eleonorae in Algeria.' Bird Conservation International.doi:10.1017/S0959270916000484

Viñuela, J., and C. Sunyer. 1992. 'Nest Orientation and Hatching Success of Black Kites Milvus migrans in Spain.' Ibis 134 (4): 340-345.

Viñuela, J., and J. P. Veiga. 1992. 'Importance of Rabbits in the Diet and Reproductive Success of Black Kites in Southwestern Spain.' Ornis Scandinavica 23: 132-138.

Zawadzka, D. 1999. 'Feeding Habits of the Black Kite Milvus migrans, Red Kite Milvus milvus, White-Tailed Eagle Haliaeetus albicilla and Lesser Spotted Eagle Aquila pomarine inWigry National Park (NE Poland).' Acta ornithologica 34: 65-75.

Zocchi, A., L. Lacroix. 2004. 'The Colony of Black Kite (Milvus migrans): Status, Nest-Tree Characteristics and Anthropogenic Disturbance (Aves, Accipitridae).' Ricerche naturalistiche a boscodellafontana - quaderniconservazione habitat 3: 71-78. 